\title{
Effect of Alccofine on the Properties of Concrete Incorporating Steel Fibers
}

\author{
Akula Rajani, Kurendha Geetha
}

\begin{abstract}
This paper deals with the investigation of concrete containing varying replacement percentages of Alccofine and conjointly Alccofine and different proportions of steel fibers with aspect ratio 50 to investigate mechanical and morphological properties. The replacement levels of Alccofine was chosen as $5 \%$ to $15 \%$ with $5 \%$ increment and steel fibers of $0.5 \%$ to1.5\% with an increment of $0.5 \%$ by volume of concrete. Mix design was done by using British D.O.E method, fixing water binder ratio as 0.45. Results indicated that concrete replaced with Alccofine in addition of steel fibers increased the compressive and flexural strength of concrete. The maximum strength was obtained for the concrete mix containing 15\% Alccofine and 1.5\% circular crimped steel fibers. Morphological studies indicated the excess $C-S-H$ gel for concrete mixes containing Alccofine as compared to conventional concrete. Hence, it can be culminated that Alccofine and addition of steel fibers increases the strength properties and crack resistant strength of concrete.

Keywords : Alccofine, British D.O.E method, steel fibers.
\end{abstract}

\section{INTRODUCTION}

Concrete quality will not only depends upon the strength properties but also depends on improving the durability of the concrete, reducing the porosity and thereby producing greener concrete [1]. Hence alternative material for cement is significant so as to reduce the impact of global warming and thereby satisfying the required properties of concrete [2]. Concrete being brittle material, provides very little resistance to cracking, which develops internal micro cracks thereby causing fractures in the concrete. Hence by addition of fibers to the concrete, they improve dynamic and static properties and acts as crack resistant [3]. In the present study, the effects of Alccofine incorporated with and without steel fibers on the mechanical and morphological properties were examined. Chakravarthy et al., [4] had done the analysis on compressive strength with partial replacement of cement with Alccofine and compared the results with conventional concrete and concluded that the compressive strength was maximum at $16 \%$ and on further the strength decreased. Krishnaraj et al., [5] had done the experimental investigation on the concrete admixed with Alccofine and fly-ash with and without super-plasticizer and from the results obtained authors

Revised Manuscript Received on April 27, 2020.

* Correspondence Author

Akula Rajani*, Assistant Professor, Department of Civil Engineering, Princeton Instuite of Engineering and Technology for Women, Hyderabad, India. Email: akularajni@gmail.com

Kurendha Geetha, Assistant Professor, Department of Civil Engineering, Princeton Instuite of Engineering and Technology for Women, Hyderabad, India. Email: geethakurendha4@gmail.com

(c) The Authors. Published by Blue Eyes Intelligence Engineering and Sciences Publication (BEIESP). This is an open access article under the CC BY-NC-ND license (http://creativecommons.org/licenses/by-nc-nd/4.0/) concluded that blending of Alccofine and fly ash will increase the strength and durability properties. Surendra et al., [6] has conducted the experimental study on the strength of concrete containing GGBS and Alccofine and concluded that strength increases with replacement of cement by GGBS and Alccofine because of the hydraulic properties and better compaction of Alccofine and GGBS. Kaur et al., [7] investigated experimentally various properties of mixed fiber reinforced concrete for structural application and from the results obtained authors concluded that utilization of fibers in concrete improves the static and dynamic properties and increases the ability to sustain a load without excessive deformation. Ghaffar et al., [8] had done research on the usage of steel fibers in concrete to enhance the mechanical properties and concluded that inclusion of steel fibers improves the various strengths and gain of strength also depends on the amount of fiber content in concrete.

\section{EXPERIMENTAL INVESTIGATION}

\section{A. Materials utilized}

\section{- Cement}

In present investigation, 53 grade ordinary Portland cement (OPC) satisfying IS: 12269-1987 [9] was used. The physical properties and chemical composition of OPC are listed below.

Table I: Physical properties of OPC

\begin{tabular}{|c|c|}
\hline Properties & Result \\
\hline Specific gravity of cement & 3.15 \\
\hline Normal consistency & $33 \%$ \\
\hline Fineness of cement & $0.0075\left(\mathrm{~cm}^{2} / \mathrm{gm}\right)$ \\
\hline Initial setting time & 57 minutes \\
\hline Final setting time & 600 minutes \\
\hline
\end{tabular}

Table II: Chemical composition of OPC

\begin{tabular}{|c|c|}
\hline Constituent (wt.) & Percentage (\%) \\
\hline $\mathrm{SiO}_{2}$ & 23.47 \\
\hline $\mathrm{Al}_{2} \mathrm{O}_{3}$ & 5.06 \\
\hline $\mathrm{Fe}_{2} \mathrm{O}_{3}$ & 3.5 \\
\hline $\mathrm{CaO}$ & 59.77 \\
\hline $\mathrm{MgO}$ & 3.32 \\
\hline $\mathrm{SO}_{3}$ & 1.43 \\
\hline
\end{tabular}

- Alccofine

Published By:

Blue Eyes Intelligence Engineering \& Sciences Publication 
Alccofine used in the present investigation was procured from SN Enterprise, Bangalore. The physical properties and chemical composition was obtained from the Alccofine manufacturer and listed in Table III and Table IV.

Table III: Physical properties of Alccofine

\begin{tabular}{|c|c|}
\hline Properties & Result \\
\hline Specific gravity & 2.9 \\
\hline Fineness $\left(\mathrm{cm}^{2} / \mathrm{gm}\right)$ & $>12000$ \\
\hline Bulk density $\left(\mathrm{kg} / \mathrm{m}^{3}\right)$ & $800-900$ \\
\hline
\end{tabular}

Table IV: Chemical composition of Alccofine

\begin{tabular}{|c|c|}
\hline Constituent (wt.) & Percentage (\%) \\
\hline $\mathrm{SiO}_{2}$ & 34.68 \\
\hline $\mathrm{Al}_{2} \mathrm{O}_{3}$ & 16.5 \\
\hline $\mathrm{Fe}_{2} \mathrm{O}_{3}$ & 1.9 \\
\hline $\mathrm{CaO}$ & 62.13 \\
\hline $\mathrm{MgO}$ & 8.23 \\
\hline $\mathrm{SO}_{3}$ & 0.44 \\
\hline
\end{tabular}

\section{- Coarse aggregate}

Coarse aggregate of size $20 \mathrm{~mm}$ and $10 \mathrm{~mm}$ were used in the present investigation and the proportion used were of $65 \%$ and $35 \%$ of the total weight of coarse aggregate, with specific gravity 2.59 and 2.58 respectively.

\section{- Fine aggregate}

River sand was used throughout the investigation and the specific gravity was determined using pycnometer in accordance with IS: 2328-1963(part III) [10] and obtained specific gravity was 2.66 of grading zone II as per IS: 383-1970 [11].

\section{- Steel fibers}

Crimped circular steel fibers were adopted in the present investigation. The properties of crimped circular steel fibers were presented in Table V confirming to ASTM A820.

Table V: Properties of crimped circular steel fibers

\begin{tabular}{|c|c|c|c|}
\hline Properties & Diameter & Length & Aspect ratio \\
\hline Values & $0.60 \mathrm{~mm}$ & $50 \mathrm{~mm}$ & 50 \\
\hline
\end{tabular}

- Water

Tap water was used in this investigation for mixing and moist curing.

\section{B. Mix proportioning}

The concrete mix was prepared at water binder ratio 0.45 . The concrete mix design was carried out using DOE method (British mix design method) with some modifications. Concrete mix proportion is presented in Table VI.

Table VI: Mix proportion of concrete for OPC

\begin{tabular}{|c|c|c|c|}
\hline $\begin{array}{c}\text { Cement } \\
\left(\mathrm{kg} / \mathrm{m}^{3}\right)\end{array}$ & $\begin{array}{c}\text { Water } \\
\left(\mathrm{kg} / \mathrm{m}^{3}\right)\end{array}$ & $\begin{array}{c}\text { Fine } \\
\text { aggregate } \\
\left(\mathrm{kg} / \mathrm{m}^{3}\right)\end{array}$ & $\begin{array}{c}\text { Coarse } \\
\text { aggregate } \\
\left(\mathrm{kg} / \mathrm{m}^{3}\right)\end{array}$ \\
\hline 422.22 & 190 & 616.97 & 1145.80 \\
\hline
\end{tabular}

\section{Preparation of concrete specimens}

Cube specimen and prismatic specimen were prepared using ordinary Portland cement (OPC) for different concrete mix shown in Table VII. After 24 hours of casting, the concrete specimens were subjected to curing until the age of 28 days and 56 days. After curing, specimens were tested for compressive and flexural strength of concrete.

Table VII: Different concrete mixes with varying percentages of Alccofine and crippled circular steel fibers

\begin{tabular}{|c|c|}
\hline Concentration & Abbreviation \\
\hline Control mix & A0F0 \\
\hline $5 \%$ Alccofine $+0 \%$ steel fibers & A1F0 \\
\hline $5 \%$ Alccofine $+0.5 \%$ steel fibers & A1F1 \\
\hline $5 \%$ Alccofine $+1 \%$ steel fibers & A1F2 \\
\hline $5 \%$ Alccofine $+1.5 \%$ steel fibers & A1F3 \\
\hline $10 \%$ Alccofine $+0 \%$ steel fibers & A2F0 \\
\hline $10 \%$ Alccofine $+0.5 \%$ steel fibers & A2F1 \\
\hline $10 \%$ Alccofine $+1 \%$ steel fibers & A2F2 \\
\hline $10 \%$ Alccofine $+1.5 \%$ steel fibers & A2F3 \\
\hline $15 \%$ Alccofine $+0 \%$ steel fibers & A3F0 \\
\hline $15 \%$ Alccofine $+0.5 \%$ steel fibers & A3F1 \\
\hline $15 \%$ Alccofine $+1 \%$ steel fibers & A3F2 \\
\hline $15 \%$ Alccofine $+1.5 \%$ steel fibers & A3F3 \\
\hline
\end{tabular}

\section{RESULTS AND DISCUSSIONS}

\section{A. Compressive strength of concrete}

Cube specimens of different proportions were tested after the curing period of 28 and 56 days for compressive strength in a hydraulically operated machine as per IS: 516:1959. The results were graphically presented in Fig. 1.

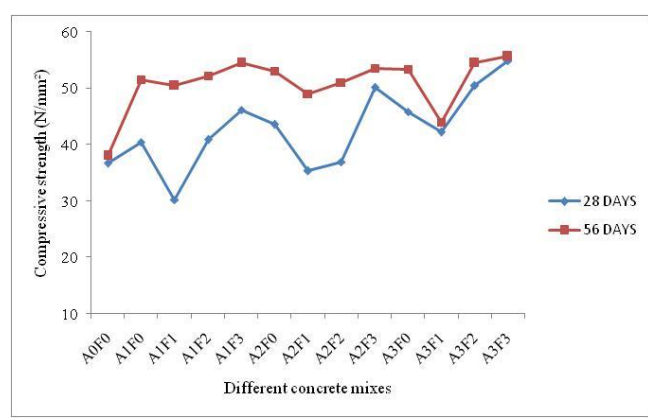

Fig. 1. Compressive strength of concrete containing different proportions of Alccofine and conjointly Alccofine and crimped circular steel fibers

From Fig. 1, it is perceived that concrete replaced with $15 \%$ Alccofine incorporated with $1.5 \%$ of steel fibers showed higher strength than conventional concrete and other concrete mixes at both the ages of curing. It is also observed that on increasing the percentage of steel fibers to concrete replaced with varying percentages of Alccofine strength has been gradually increased and achieved maximum strength on addition of steel fibers of $1.5 \%$. Concrete replaced with different percentages of Alccofine irrespective of steel fibers, it was also perceived that strength increases on increasing the percentage replacement of Alccofine and yielded maximum strength for $15 \%$ replacement.

Published By:

Blue Eyes Intelligence Engineering \& Sciences Publication

(C) Convriaht: All riahts reserved. 
The increase in compressive strength may be due to the formation of additional C-S-H gel due to the increase in Alccofine content in concrete and also may be due to the physical property of high fineness Alccofine. Presence of crimped circular steel fibers also improved the compressive strength by providing resistance against cracks and improving the ductility. It is also observed that, concrete containing $0.5 \%$ steel fibers with varying proportions of Alccofine, strength has been slightly decreased compared to concrete containing Alccofine irrespective of steel fibers. But as the curing period increased the strength has been gradually increased and yielded better strength than conventional concrete.

\section{B. Flexural strength test}

Prismatic specimens of different concrete mixes were tested after 28 and 56 days of curing and the results obtained were presented in Fig. 2.

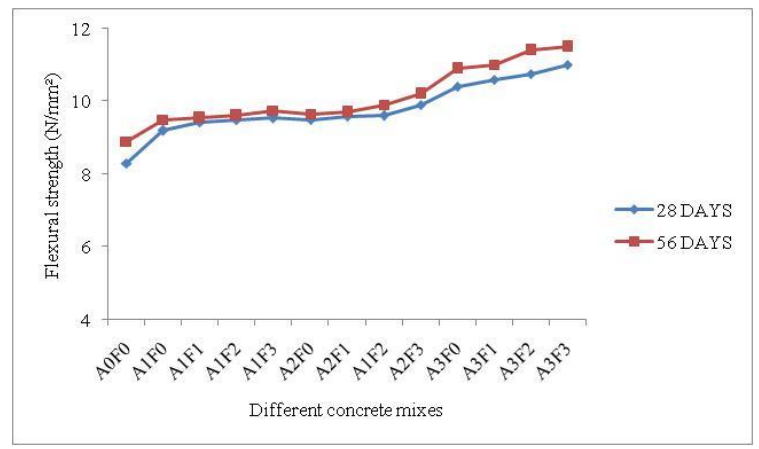

Fig. 2: Flexural strength of concrete containing varying proportions of Alccofine and conjointly Alccofine and crimped circular steel fibers

From Fig. 2, it is observed that on increasing the percentage replacement of Alccofine and conjointly Alccofine and different proportion of steel fibers the strength has been gradually increasing and yielded more strength than the control concrete at the curing period of 28 and 56 days. The optimum strength was achieved for the concrete mix containing $15 \%$ Alccofine incorporated with $1.5 \%$ of steel fibers. The increase in strength due to Alccofine may be due to the secondary formation of C-S-H gel, high density and high packing value of Alccofine and also may be due to the voids filling capacity of Alccofine due to its high fineness. Presence of steel fibers arresting the internal cracks caused in the tension zone and thereby attributing to the increase in strength of concrete.

\section{Morphological properties}

In the present investigation, scanning electron microscopy was conducted to study morphological changes in concrete. SEM micrograph of conventional concrete and concrete replaced with $15 \%$ Alccofine on addition of $1.5 \%$ steel fibers is presented in Fig. 3 and Fig. 4 respectively. More formation of calcium silicate hydrate gel has been observed from Figure 4 as compared to Fig. 3. Also formation of hexagonal shapes has been observed from Fig. 4, conforming calcium hydroxide.

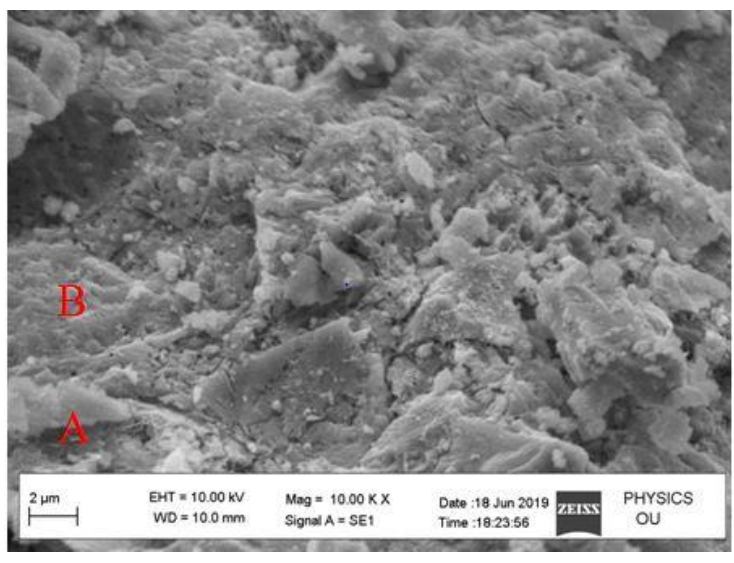

Fig. 3: SEM micrograph of conventional concrete A) C-S-H gel B) Gypsum

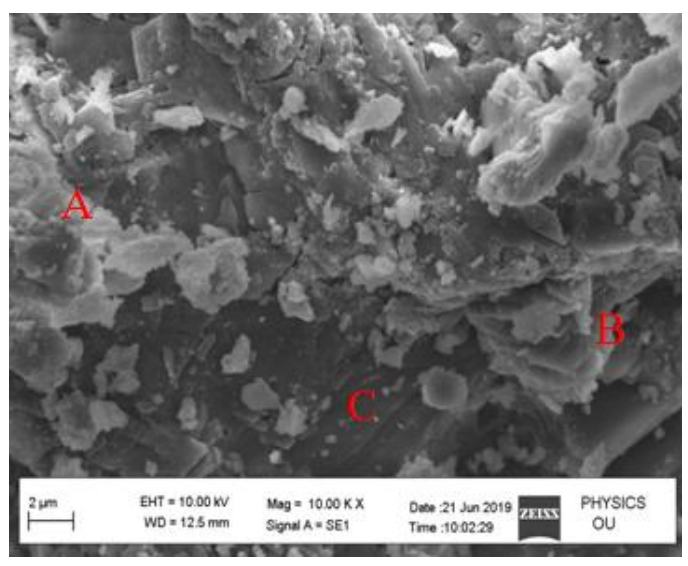

Fig. 4: SEM micrograph of concrete A3F3
A) C-S-H gel B) $\mathrm{Ca}(\mathrm{OH})_{2}$ C) Gypsum

\section{CONCLUSION}

1. The concrete containing $15 \%$ replacement of cement with Alccofine gave optimum strength and workability. On addition of steel fibers also, the mixes were workable due to the presence Alccofine.

2. Compressive strength of concrete when replaced with $15 \%$ Alccofine is found to be $40 \%$ greater than the strength of conventional concrete.

3. Compressive strength of concrete replaced with $15 \%$ Alccofine and addition of $1.5 \%$ crimped circular steel fibers yielded $47 \%$ more than the conventional concrete. The increase in strength with the increase in percentage of steel fibers may be due to the lack of internal cracks in concrete as the steel fibers as a crack arrestor.

4. Flexural strength was found maximum for mix containing high content of Alccofine and steel fibers i.e. 15\% Alccofine and $1.5 \%$ steel fibers. At both the curing periods all concrete mixes containing Alccofine and conjointly Alccofine and steel fibers yielded maximum strength than conventional concrete.

Published By:

Blue Eyes Intelligence Engineering \& Sciences Publication (C) Convriaht: All riahts reserved. 
5. Scanning electron micrographs indicate dense formation of calcium silicate hydrate gel and calcium hydroxide in the concrete mix replaced with $15 \%$ Alccofine incorporated with $1.5 \%$ steel fibers, which attributed to the gain of strength in concrete.

\section{REFERENCES}

1. Gayathri, K., Ravichandran, K., and Saravanan, J. (2016). "Durability and Cementing Efficiency of Alccofine in Concretes." International Journal of Engineering Research \& Technology, 5(05), 460-468.

2. Faisal, K. M. (2016). "Effect of glass fiber on Alccofine mix concrete." International Journal of Scientific \& Engineering Research, 7(10), 31-35.

3. Lim, D. T. Y., Divsholi, B. S., Kondraivendhan, B., and Teng, S. (2011). "Effect of ultra fine slag replacement on durability effect of ultra fine slag replacement on durability." $36^{\text {th }}$ Conference in Our World in Concrete \& Structures, August 14-16.

4. Chakravarthy, P. R. C. and RathanRaj. R., (2017). "Analysis on Compressive Strength of Concrete with Partial Replacement of Cement with Alccofine". International Research Journal of Engineering and Technology (IRJET), (12), 8.

5. Krishnaraj, L., Madhusudhan, N., and Ravichandran, P. T. (2017). "Experimental study of Ultra fine particles in mechanical and durability properties of Fly Ash cement composite mortar." ARPN Journal of Engineering and Applied Sciences, 12(7), 2297-2305.

6. Surendra, B. V, and Rajendra, T. N. (2017). "An Experimental Study on Strength of concrete using GGBS and Alcofine." International research Journal of Engineering and Technology, 706-709.

7. Kaur, P. (2017). "Different types of Fibers used in FRC." International Journal of Advanced Research in Computer Science, 8(4), 2015-2018.

8. Ghaffar, A. (2014). "Steel Fiber Reinforced Concrete." International Journal of Engineering Trends and Technology, 9(15), 791-797.

9. Indian standards IS 12269(1987): 53 grade ordinary portland cement

10. IS: 2386-1963(part I, part III): methods of test for aggregates for concrete.

11. IS: 383: 1970: specifications for Fine and Coarse aggregates for concrete

12. IS: 516-1959: method of tests for strength of concrete

13. Gowdham. K, Sumathi. A, Mohan. K. S. R. (2017). "Study on the Strength Characteristics of High strength Concrete with micro Steel Fibers". Earth and Environmental Science, 80.

14. Gupta, A. K. (2018). "Experimental investigation to find the optimum dose of steel fibers in concrete incorporating ultra fine slag." Journal of Engineering Science and technology,13(1), 187-195.

15. Gupta, S., Sharma, S., and Sharma, E. D. (2015). "A Review on Alccofine: A supplementary cementitious material." International Journal of Modern Trends in Engineering and Research, 2(8), 114-119.

16. Shende, A. M., Pande, A. M., and Pathan, M. G. (2012). "Experimental Study on Steel Fiber Reinforced Concrete for M-40 Grade." 1(1), 43-48.

\section{AUTHORS PROFILE}

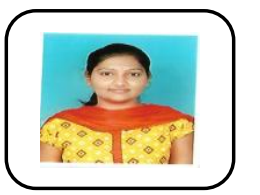

Akula Rajani, Assistant professor, Department of Civil Engineering, Princeton instuite of Engineering and Technology for Women, Chowdaryguda Village, Ghatkesar,Telangana-500088.,

Email: akularajni@gmail.com

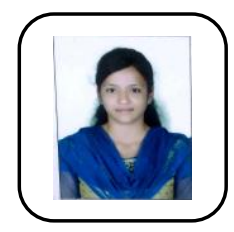

Kurendha Geetha, Assistant professor, Department of Civil Engineering, Princeton instuite of Engineering and Technology for Women, Chowdaryguda Village, Ghatkesar,Telangana-500088.,

Email: geethakurendha4@gmail.com 